\title{
Sistem Monitoring dalam Penanganan Kerusakan Peralatan Elektronik di STMIK STIKOM Indonesia
}

\author{
Aniek Suryanti Kusuma ${ }^{1}$, Welda ${ }^{2}$ \\ STMIK STIKOM Indonesia \\ 1anieksuryanti@yahoo.com, ${ }^{2}$ welda_w@yahoo.com
}

\begin{abstract}
ABSTRAK.Sistem monitoring dalam penanganan kerusakan peralatan elektronik di STMIK STIKOM Indonesia saat inidilaksanakan dengan melakukan pencatatan di buku besar.Kendala yang dihadapi adalah sering terjadinya kesimpang siuran informasi peralatan yang sudah diperbaiki dan yang belum diperbaiki.Teknisi yang telah memperbaiki kadang tidak melaporkan ke Bagian Rumah Tangga hasil dari perbaikan tersebut.Hal ini menyebabkan Bagian Rumah Tangga, BAA, dan PK II tidak tahu informaasi mengenai kondisi peralatan saat itu sehingga pelayanan STMIK STIKOM Indonesia terhadap dosen dan mahasiswa menjadi kurang efektif.Penelitian ini akan diawali dengan melakukan observasi terhadap sistem yang sudah ada kemudian dilanjutkan dengan requirement analysis dari pengguna sistem dan berikutnya dilakukan proses pengembangan sistem. Tahap akhir dari penelitian ini adalah melakukan pengujian dengan menggunakan metode black box testing. Sistem monitoring penanganan kerusakan peralatan elektronik ini dibangun dengan tujuan dapat memantau penanganan kerusakan peralatan yang dilakukan oleh teknisi.Proses monitoring akan diawali dengan penginputan data kerusakan oleh bagian rumah tangga yang kemudian dapat langsung dilihat oleh bagian teknisi dan PK II. Jika perbaikan telah selesai dilakukan maka bagian teknisi akan menginputkan status dan tanggal selesainya perbaikan tersebut. Dengan adanya sistem ini diharapkan dapat meningkatkan kualitas pelayananpada STMIK STIKOM Indonesia.
\end{abstract}

Kata Kunci: Monitoring, peralatan, Black Box Testing

\section{PENDAHULUAN}

STMIK STIKOM Indonesia sebagai salah satu institusi di bidang pendidikan yang berbasis komputer memiliki banyak peralatan elektronik khususnya komputer. Pada masing-masing kelas terdapat peralatan elektronik seperangkat komputer dan LCD yang digunakan oleh dosen untuk mengajar. Jika peralatan dalam ruangan mengalami kerusakan maka proses belajar mengajar akan sangat terganggu. Sistem penanganan kerusakan yang berlangsung saat ini adalah masih dicatat pada buku besar.Jumlah teknisi di STMIK STIKOM Indonesia ada dua dan jam kerjanya berbeda setiap harinya, kerusakan peralatan yang ditangani juga cukup banyak. Sehingga terkadang ada kebingungan di bagian teknisi mengenai peralatan yang mana sudah ditangani dan yang belum ditangani.Bagian rumah tangga juga kadang tidak tahu mana peralatan yang sudah diperbaiki atau belum karena pihak teknisi sering lupa untuk menginformasikannya.Hal ini mengakibatkan kesalahan informasi sehingga kadang ada peralatan yang tidak ditangani dengan cepat.

Peningkatan pelayanan mengenai penanganan kerusakan pada peralatan elektronik dapat direpresentasikan dengan berbagai macam cara, salah satunya adalah dengan sistem monitoring kerusakan peralatan elektronik yang berbasis komputer sehingga dapat diakses langsung oleh Bagian Rumah Tangga dan Teknisi serta dapat dilakukan pemantauan oleh Pembantu Ketua II. Hal ini nantinya diharapkan dapat memberikan informasi yang valid tentang kerusakan ataupun alat elektronik yang sudah diperbaiki oleh teknisi.Sistem tersebut dapat menerima inputdari rumah tangga ataupun dari BAAK mengenai laporan kerusakan peralatan di seluruh ruangan yang ada di STMIK STIKOM Indonesia.Pihak teknisi juga dapat menginputkan status peralatan elektronik apakan sudah diperbaiki ataupun belum.

Sistem monitoring penanganan kerusakan peralatan elektronik dibangun dengan tujuanuntuk memantau dan menangani dengan cepat segala kerusakan peralatan elektronik yang ada di STMIK STIKOM Indonesia sehingga dapat meningkatkan kualitas pelayanan. Sistem ini juga mampu untuk menghasilkan laporan peralatan yang belum diperbaiki dan yang telah diperbaiki oleh masing-masing teknisi.

Rumusan masalah dalam penelitian ini adalah bagaimana rancang bangun sistem monitoring dalam penanganan kerusakan peralatan di STMIK STIKOM Indonesia untuk meningkatkan kualitas pelayanan?

Tujuan dari penelitian ini adalah untuk merancang bangun sistem monitoring dalam penanganan kerusakan di STMIK STIKOM Indonesia diharapkan dapat meningkatkan kualitas pelayanan kepada mahasiswa atupun dosen pengampu matakuliah.

Dengan dilakukannya penelitian ini, diharapkan dapat memberikan manfaat bagi STMIK STIKOM Indonesia, diantaranya: 
a. Memudahkan petugas BAA dalam melakukan pencatatan kerusakan peralatan di ruangan.

b. Memudahkan Pembantu Ketua II untuk memantau penanganan kerusakan peralatan.

c. Mempermudah dalam mengetahui kinerja teknisi melalui informasi yang dihasilkan sebagai dasar dan bahan pertimbangan untuk perbaikan kinerja teknisi secara berkesinambungan.

\section{LANDASAN TEORI}

\subsection{Konsep Dasar Sistem}

Sistem merupakan kumpulan dari elemen-elemen yang berinteraksi untuk mencapai suatu tujuan tertentu.Menurut Jerry FithGerald, "sistem adalah suatu jaringan kerja dari prosedur-prosedur yang saling berhubungan, berkumpul bersama-sama untuk melakukan suatu kegiatan atau menyelesaikan suatu sasaran tertentu" (Jogiyanto, 2005).

\subsection{Data, Informasi, dan Pengetahuan}

Informasi merupakan salah satu sumber daya penting dalam manajemen modern.Banyak keputusan strategis yang bergantung kepada informasi.Informasi tidak hanya dipakai untuk kepentingan internal dalam organisasi, tetapi juga dapat dipakai pihak eksternal (di luar organisasi).Perbedaan antara data dan informasi sering menjadi titik awal untuk memahami sistem informasi (Kadir, 2003).

a. Data

Secara konseptual, data adalah deskripsi tentang benda, kejadian, aktivitas, dan transaksi kepada pemakai.Data dapat berupa nilai yang terformat, teks, citra, audio, dan video.

b. Informasi

Menurut McFadden, dkk (Kadir, 2003) informasi data yang telah diproses sedemikian rupa sehingga meningkatkan pengetahuan seseorang yang menggunakan data tersebut.Menurut Davis (Kadir, 2003), informasi adalah data yang telah diolah menjadi sebuah bentuk yang berarti bagi penerimanya dan bermanfaat dalam pengambilan keputusan saat ini atau saat mendatang.

c. Pengetahuan

Menurut Alter (Kadir, 2003), pengetahuan (knowledge) adalah kombinasi dari naluri, gagasan, aturan, dan prosedur yang mengarahkan tindakan atau keputusan. Sebagai gambaran, informasi yang dipadukan dengan pengalaman masa lalu dan keahlian akan memberikan suatu pengetahuan yang tentu saja memiliki nilai yang tinggi.

\subsection{Monitoring}

Beberapa pakar manajemen mengemukakan bahwa fungsi monitoring mempunyai nilai yang sama bobotnya dengan fungsi perencanaan. Pada umumnya, manajemen menekankan terhadap pentingnya kedua fungsi ini, yaitu perencanaan dan pengawasan(monitoring).

Kegiatan monitoring dimaksud untuk mengetahui kecocokan dan ketepatan kegiatan yang dilaksanakan dengan rencana yang telah disusun.Monitoring digunakan pula untuk memperbaiki kegiatan yang menyimpang dari rencana, mengoreksi penyalahgunaan aturan dan sumber-sumber, serta untuk mengupayakan agar tujuan dicapai seefektif dan seefisien mungkin.

\subsection{PengertianPeralatan Elektronik}

J. Millman dalam bukunya Micro Electronics menyatakan bahwa Elektronika adalah ilmu dan teknologi tentang melintasnya partikel bermuatan listrik di dalam suatu gas atau suatu ruang hampa, atau suatu semikonduktor (Millman, 1979). Sedangkan Ivan Sudirman dan Romi Satria Wahono mendefinisikan Peralatan Elektronik sebagai suatu peralatan yang bekerjanya secara elektronik penuh (Sudirman dan Wahono, 2003).

Lahirnya elektronika sebenarnya mula-mula atas tuntutan kebutuhan manusia akan sarana telekomunikasi. Sarana telekomunikasi menggunakan telepon yang ditemukan oleh A.G. Bell pada tahun 1876 masih terlalu sederhana, banyak keterbatasan-keterbatasannya.Hingga saat ini perkembangan peralatan elektronika telah jauh melampaui teknologi di masa dulu.

\subsection{SystemDevelopment Life Cycle (SDLC)}

SDLC merupakan proses mengembangkan atau mengubah suatu sistem perangkat lunak dengan menggunakan model-model dan metodologi yang digunakan orang untuk mengembangkan sistem-sistem perangkat lunak sebelumnya (berdasarkan best practice atau cara-cara yang sudah teruji baik). Tahapan-tahapan yang ada pada SDLC secara global adalah sebagai berikut : inisiasi (initiation), pengembangan konsep sistem (system concept development), perencanaan (planning), analisis kebutuhan (requirementsanalysis), desain (design), pengembangan (development), integrasi dan pengujian (integration and test), implementasi (implementation), operasi dan pemeliharaan (operations and maintenance), dan disposisi (disposition). 
SDLC memiliki beberapa model dalam penerapan tahapan prosesnya, salah satunya adalah model waterfall. Model ini menyediakan pendekatan alur hidup perangkat lunak secara sekuensial atau terurut dimulai dari analisis, desain, pengodean, pengujian, dan tahap pendukung (support). Gambar 1 berikut adalah ilustrasi model waterfall.

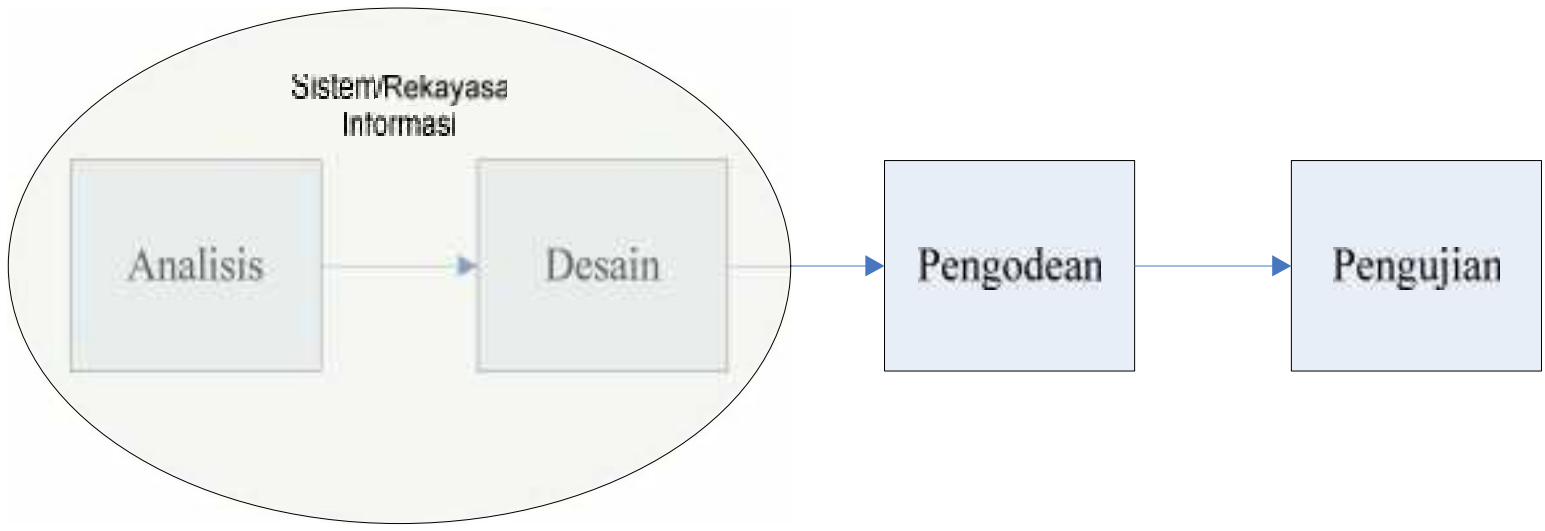

Gambar 1. Ilustrasi Model Waterfall

\subsection{Data Flow Diagram}

DFD adalah suatu model logika data atau proses yang dibuat untuk menggambarkan asal data dan tujuan data yang keluar dari sistem, tempat penyimpanan data, proses apa yang menghasilkan data tersebut serta interaksiantara data yang tersimpan dan proses yang dikenakan pada data tersebut (Kusrini, 2007).

Ada dua jenis DFD, yaitu DFD logis dan DFD fisik. DFD logis menggambarkan proses tanpa menyarankan bagaimana mereka akan melakukan, sedangkan DFD fisik menggambarkan proses model berikut implementasi pemrosesan informasinya (Al Fatta, 2007).

Ada beberapa metode untuk menggambarkanelemen-elemen tersebut yang ditunjukkan pada Tabel 1.

Tabel 1. Simbol Data Flow Diagram

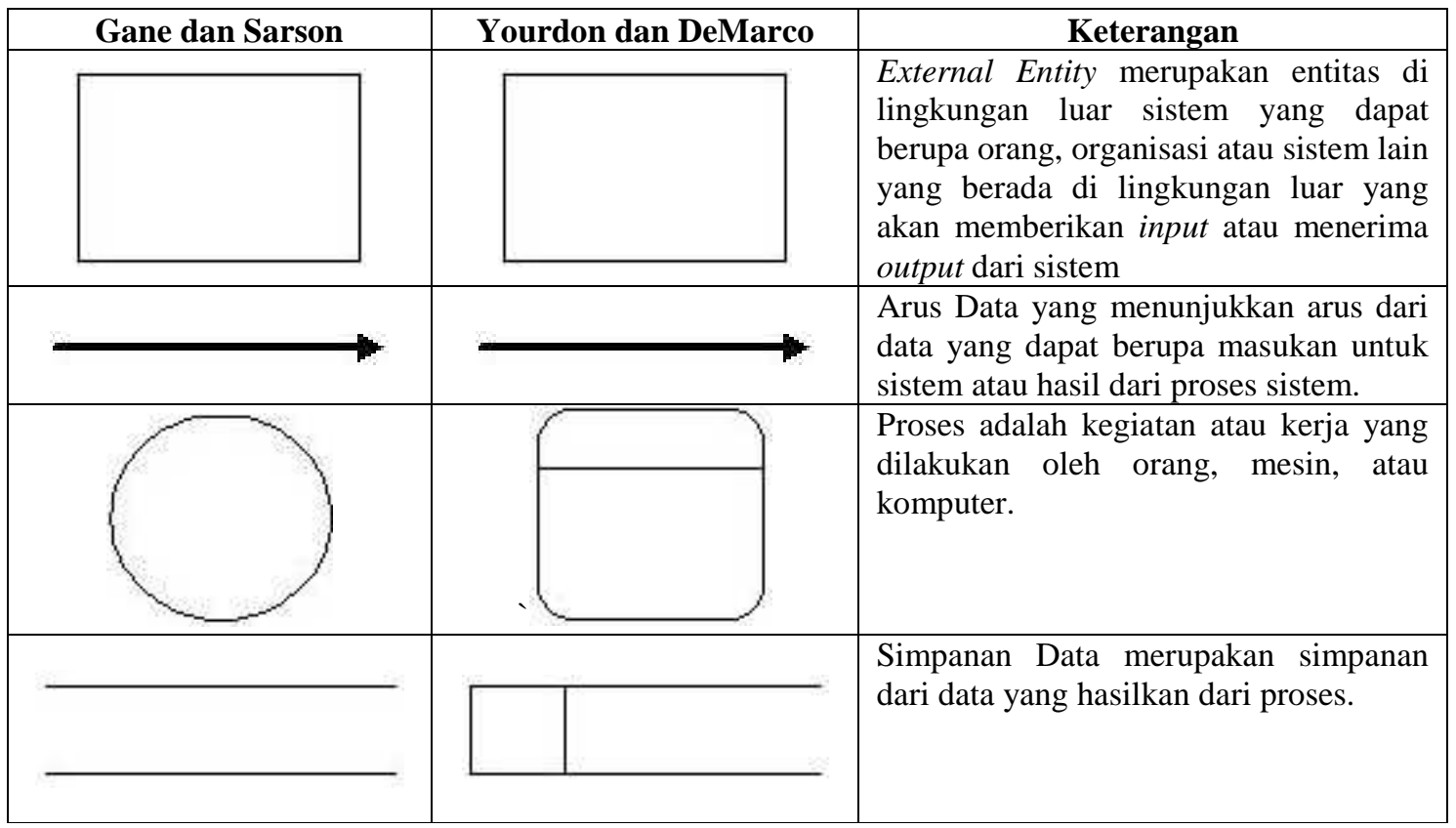




\subsection{Entity Relationship Diagram}

ERD adalah gambar atau diagram yang menunjukkan informasi dibuat, disimpan dandigunakan dalam sistem bisnis (Al Fatta, 2007). Entitas biasanya menggambarkan jenis informasi yang sama. Elemen-elemenyang ada pada ERD ditampilkan pada Tabel 2.

Tabel 2. Simbol Entity Relationship Diagram

\begin{tabular}{|l|l|}
\hline \multicolumn{1}{|c|}{ Simbol } & \multicolumn{1}{|c|}{ Keterangan } \\
\hline Enites & $\begin{array}{l}\text { Entity merupakan suatu objek atau konsep } \\
\text { mengenai tempat yang anda inginkan untuk } \\
\text { menyimpan }\end{array}$ \\
\hline & $\begin{array}{l}\text { Relationships mengilustrasikan bagaimana dua } \\
\text { entitas berbagi informasi di dalam struktur basis } \\
\text { data. }\end{array}$ \\
\hline & $\begin{array}{l}\text { Attributes adalah sifat-sifat atau karakteristik dari } \\
\text { suatu entitas }\end{array}$ \\
\hline & $\begin{array}{l}\text { Penghubung antara relasi dan entitas di mana di } \\
\text { kedua ujungnya memiliki multiplicity kemungkinan } \\
\text { jumlah pemakaian }\end{array}$ \\
\hline
\end{tabular}

\subsection{Pemrograman Berbasis Web}

Internet adalah kelompok atau kumpulan dari jutaan komputer.Penggunaan Internet memungkinkan kita untuk mendapatkan informasi dari komputer yang ada dalam kelompok tersebut dengan asumsi bahwa pemilik komputer memberikan ijin akses.Untuk mendapatkan sejumlah informasi, sekumpulan protokol harus digunakan, yaitu sekumpulan aturan yang menetapkan bagaimana suatu informasi dapat dikirim dan diterima.

Salah satu unsur yang paling umum digunakan dari Internet selain $e$-mail adalah World Wide Web. Dewasa ini, WWW atau yang sering juga disebut sebagai "Web" saja merupakan aplikasi Internet yang paling popular.Karena Web begitu popular, banyak orang kemudian salah mengidentikkannya dengan Internet (Simarmata, 2006).

Ada dua komponen dasar di dalam arsitektur Web, yaitu browser Web dan server Web. Browser Web menawarkan antarmuka grafis untuk pengguna dan bertanggung jawab untuk komunikasi dengan server Web.Protokol komunikasi antara browser dan server Web mengikuti protocol HTTP yang distandarisasi .

\subsection{Bahasa Pemrograman PHP}

PHP merupakan script yang menyatu dengan HTML dan berada pada server (server side HTML embedded scripting). Dengan PHP ini Anda dapat membuat beragam aplikasi berbasis web, mulai dari halaman web yang sederhana sampai aplikasi komplek yang membutuhkan koneksi ke database. PHP adalah bahasa pemrogramanscript yang paling banyak dipakai saat ini. PHP banyak dipakai untuk memrogram situs web dinamis, walaupun tidak tertutup kemungkinan digunakan untuk pemakaian lain.

Adapun kelebihan dari bahasa pemrograman PHP adalah sebuah bahasa script yang tidak melakukan sebuah kompilasi dalam penggunaanya. Web Server yang mendukung PHP dapat ditemukan dimana - mana dari mulai Apache, IIS, Lighttpd, hingga Xitami dengan konfigurasi yang relatif mudah. Dalam sisi pengembangan lebih mudah, karena banyaknya milis - milis dan developer yang siap membantu dalam pengembangan.

\subsection{MySQL}

MySQL adalah sebuah program database server yang mampu menerima dan mengirimkan datanya dengan sangat cepat, multi user serta menggunakan perintah standar SQL (Structured Query Language. MySQL merupakan sebuah database server yang free artinya kita bebas menggunakan database ini untuk keperluan pribadi atau usaha tanpa harus membeli atau membayar lisensinya. MySQL pertama kali dirintis oleh seorang programmer database bernama Michael Widenuius.MySQL juga merupakan program yang dapat mengakses suatu database MySQL yang berposisi sebagai client.Database MySQL merupakan suatu perangkat lunak 
database yang berbentuk database relasional atau dalam bahasa basis data sering kita sebut dengan Relational Database Management System (RDBMS) yang menggunakan suatu bahasa permintaan bernama SQL.

\subsection{Pengujian Perangkat Lunak}

Pengujian yang akan dilakukan pada penelitian ini adalah pengujian Black Box. Pengujian black box berfokus pada persyaratan fungsional perangkat lunak. Pengujian black box berusaha menemukan kesalahan dalam kategori : fungsi-sungsi yang tidak benar atau hilang, kesalahan interface, kesalahan dalam struktur data atau akses database eksternal, kesalahan kinerja, dan inisialisasi kesalahan terminasi (Pressman, 2002). Adapun pedoman pengujian pada metode black box adalah pengujian Grafical User Interfaces (GUI), pengujian arsitektur client/server, pengujian dokumentasi dan fasilitas help, pengujian sistem real-time.

\section{METODE PENELITIAN}

\subsection{Alur Analisis}

Dalam melakukan penelitian ini, menggunakan tahapan-tahapan pengembangan sistem yang ditunjukkan pada Gambar 2.

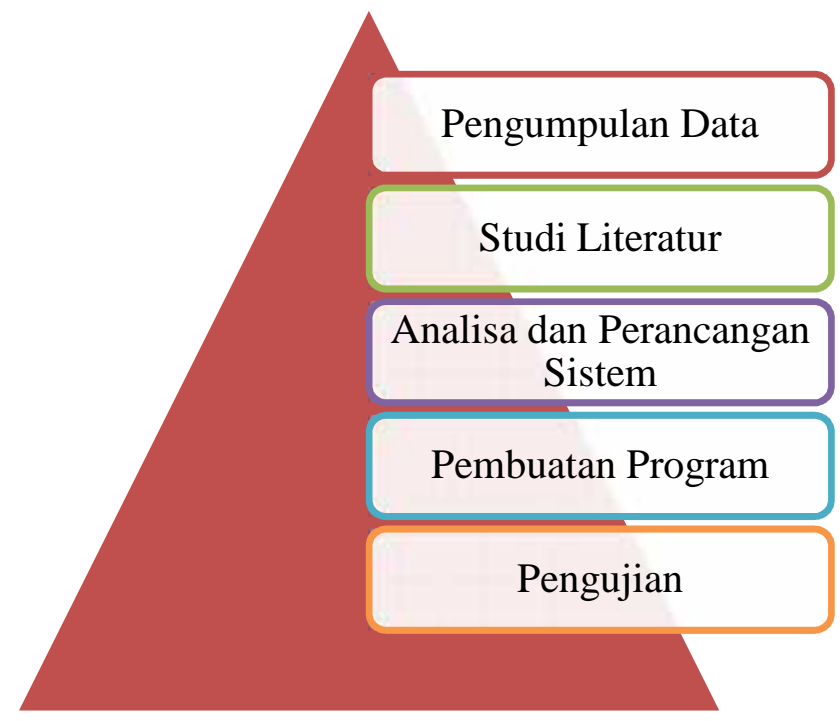

Gambar 2. Alur Analisis

\subsection{Teknik Pengumpulan Data}

\section{a. Studi Literatur}

Studi literatur merupakan metode pengumpulan data dan informasi yang diperoleh melalui sumber-sumber seperti buku, karya tulis, dan sumber lain yang berhubungan dengan objek penelitian terutama mengenai perancangan sistem informasidan blackboxtestingsehingga dapat membantu dalam proses perancangan sistem monitoring yang akan dibuat.

\section{b. Observasi}

Observasi merupakan metode pengumpulan data dan informasi yang diperoleh dengan cara melakukan pengamatan langsung terhadap objek penelitian seperti aktivitas bagian rumah tangga dalam mencatat daftar kerusakan peralatan dan menginformasikan ke bagian teknisi. Melakukan pengamatan terhadap cara penanganan kerusakan dari teknisi sampai dengan melaporkannya kembali ke bagian rumah tangga.

\section{c. Wawancara}

Wawancara dilakukan terhadap Kepala bagian Rumah Tangga dan kepada teknisi yang akan menangani kerusakan peralatan elektronik untukmencari dan menentukan kebutuhan pengguna terhadap sistem yang akan dibangun nanti.

\subsection{Gambaran Umum Sistem}

Dalam menjalankan kegiatan belajar mengajar, STMIK STIKOM Indonesia menggunakan fasilitas berupa perangkat elektronik baik komputer, LCD proyektor dan perangkat elektronik lainnya. Apabila terjadi kerusakan pada fasilitas elektronik tersebut, maka dosen pengampu matakuliah yang menggunakan fasilitas akan melaporkan kerusakan perangkat elektronik tersebut kepada BAAK untuk selanjutnya diteruskan kepada Bagian 
Rumah Tangga. Bagian Rumah Tangga bertugas mencatat komplain kerusakan ke buku besar, baik yang dilaporkan oleh BAAK maupun yang dilaporkan langsung oleh dosen pengampu.

Setelah kerusakan perangkat elektronik dicatat, Bagian Rumah Tangga akan menginformasikan kerusakan kepada Teknisi untuk segera diperbaiki. Teknisi akan menindaklanjuti dengan mengecek dan memperbaiki perangkat yang dilaporkan rusak. Apabila perangkat yang rusak telah diperbaiki, maka akan langsung dilaporkan kepada Bagian Rumah Tangga, sementara apabila perangkat yang rusak perlu dilakukan penggantian komponen ataupun penggantian perangkat baru, teknisi tetap melaporkan kepada Bagian Rumah Tangga untuk diproses pengajuan komponennya atau perangkat baru ke Bagian Keuangan.

\section{HASIL DAN PEMBAHASAN}

\subsection{Analisis Sistem}

\section{A. Kebutuhan Fungsional}

Sistem harus dapat melakukan pengolahan data PIC seperti menambahkan, mengubah, menghapus data PIC dan menyimpan ke dalam database PIC. User hanya dengan hak akses admin dapat mengelola data PIC yaitu menambah, mengubah, dan menonaktifkan PIC.

Pada sistem ini untuk data Pekerjaan Sistem juga harus dapat mengelola data pekerjaan

1. User dapat menambahkan data pekerjaan

2. User dengan Hak Akses Admin dapat mengubah semua data suatu pekerjaan.

3. User dengan Hak Akses Teknisi hanya dapat mengubah status pekerjaan, PIC, Tanggal Diselesaikan, dan keterangan.

4. User dengan hak akses admin dapat memvalidasi pekerjaan sehingga pekerjaan tersebut di anggap sudah selesai.

5. User dapat mencari data pekerjaan sesuai dengan nama PIC dan tanggal pekerjaan.

\section{B. Kebutuhan Non Fungsional}

1. Operasional

a. Sistem dapat digunakan pada sistem operasi Microsoft Windows XP, Microsoft Windows 7, Microsoft Windows 8, Microsoft Windows 10, Linux, Centos.

b. Spesifikasi komputer minimum adalah Pentium IV keatas.

c. Kebutuhan memory Ram minimal 1Gigabyte.

d. Dijalankan menggunakan media Web Browser.

e. Printer untuk mencetak data pekerjaan sebagai file laporan.

2. Keamanan

Dilengkapi dengan username dan password untuk masuk sistem dengan hak akses yang berbeda untuk atasan dan staff dalam mengakses sistem.

\subsection{Analisis Kebutuhan Perangkat Keras dan Lunak}

a. Perangkat Keras

Perangkat keras atau hardware adalah salah satu komponen dalam sebuah komputer yang sifat alatnya dapat di lihat, dan di raba secara langsung atau yang berbentuk nyata, yang berfungsi untuk mendukung proses komputerisasi.Adapun Perangkat Keras (Hardware) yang digunakan adalah:

1. Laptop dengan Processor Intel core i3 - 2370M $2.4 \mathrm{GHz}$

2. Memory RAM 4.00 GB

3. VGA Intel(R) HD Grapic 3000

b. Perangkat Lunak

Perangkat Lunak atau Software adalah data elektronik yang disimpan oleh komputer itu dapat berupa program atau instruksi yang menjalankan suatu perintah.Adapun Perangkat Lunak (Software) yang digunakan antara lain :

1. Windows 7 Ultimate 32-bit

2. Firefox Setup $46.0 \mathrm{~b} 1$

3. Google Chrome Version 48.0.2564.116 m (32-bit)

4. xampp-win32-1.8.3-0-VC11-installer

5. Sublime Text Build 3103 Setup

6. Adobe Photoshop CS6

7. Sql Yog 8.21 


\subsection{Event List}

Dalam pembuatan sistem terdapat beberapa langkah atau prosedur kerja yang ada, dimana langkah atau pembagian sistem dapat di lihat dalam struktur event list dibawah ini:

1. Data Login

2. Data Pekerjaan

2.1 Tambah Data Pekerjaan

2.2 Edit Data Pekerjaan

2.3 Cari Data Pekerjaan

2.4 Validasi Data Pekerjaan

3. Data PIC

3.1 Tambah Data PIC

3.2 Ubah Data PIC

3.3 Cari Data PIC

3.4 Non Aktifkan PIC

4. Laporan

1.1 Laporan Data PIC

1.2 Laporan Pekerjaan Berdasarkan PIC

1.3 Laporan Pekerjaan Yang Belum Diselesaikan

\subsection{Konteks Diagram}

Pada gambar 3 merupakan konteks diagram sistem monitoring kerusakan fasilitas pada STMIK STIKOM Indonesia.

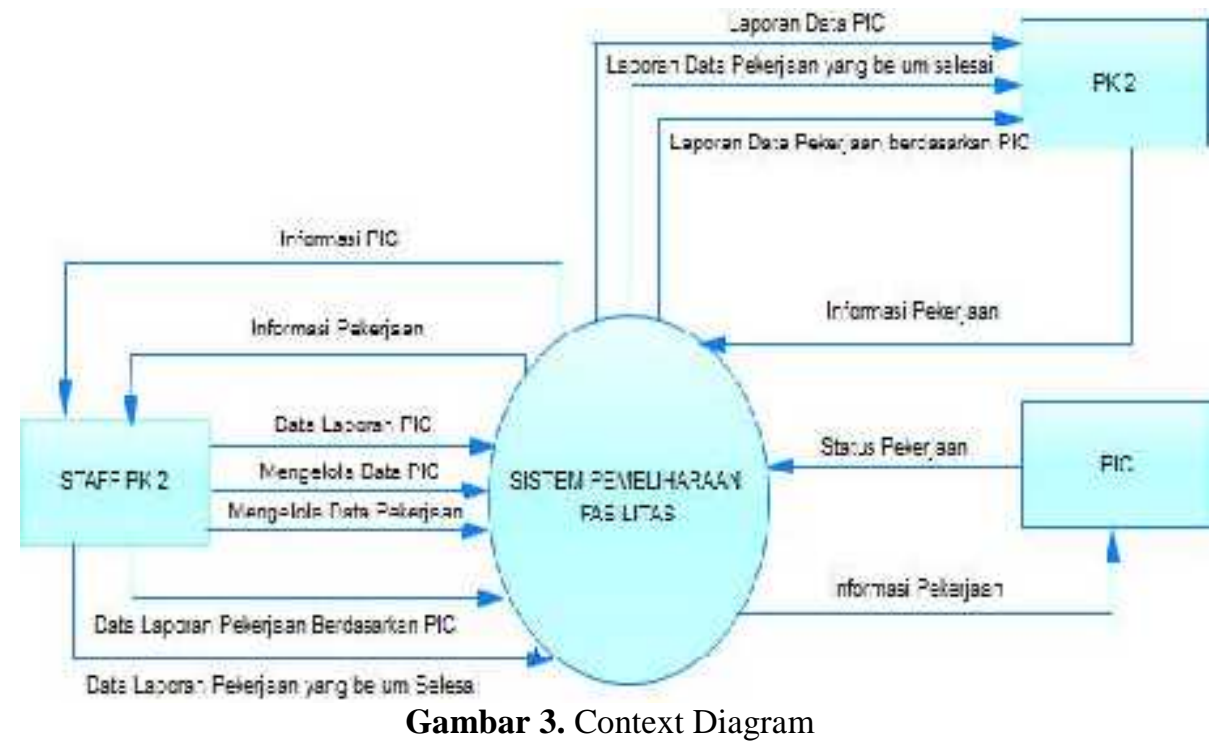

\subsection{Data Flow Diagram}

Data Flow Diagram level 0 ini menunjukkan proses-proses utama yang terjadi di dalam Sistem Pemeliharaan Fasilitas pada STMIK STIKOM Indonesia yang sedang di bangun, seperti yang ditunjukkan pada Gambar 4. 


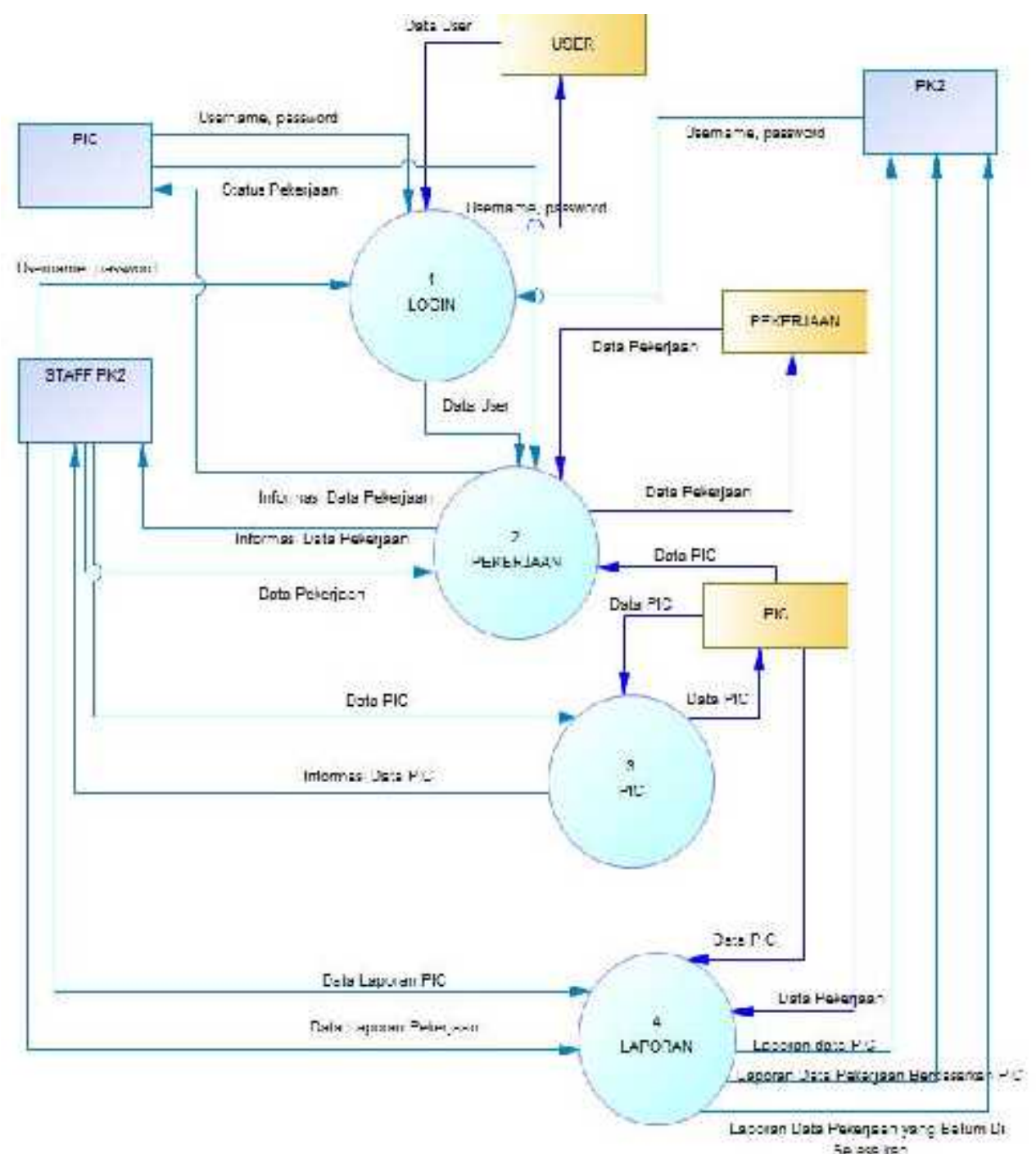

Gambar 4. DFD Level 0

Pada gambar 4 dapat digambarkan secara garis besar, pada awalnya semua user Staff PK2, PIC dan PK2 akan melakukan login terlebih dahulu selanjutnya sistem akan mengecek user akses dari masing-masing user dan kemudian masuk ke halaman Home atau halaman data pekerjaan. Staff PK2 berperan besar untuk berjalannya sistem tersebut, staff PK2 memiliki hak dalam menambah pekerjaan dan memvalidasi pekerjaan.PIC hanya memberi informasi status pekerjaan dan PK2 menerima laporan yang di perlukan.

\subsection{Conceptual Data Model}

Gambar 5 menunjukkan struktur relasi antar tabel dalam pembuatan sistem pemeliharaan fasilitas yang nantinya dari ERD ini lah yang di kembangkan menjadi database-nya yang terbuat dari MYSQL. Disini terdapat tiga tabel yaitu tabel PIC, tabel pekerjaan dan tabel user. 


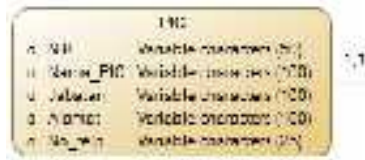

1,1

JGEP LYSES

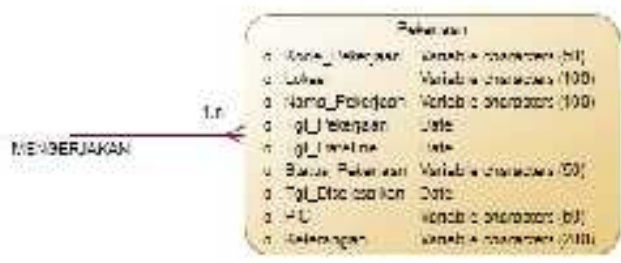

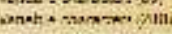

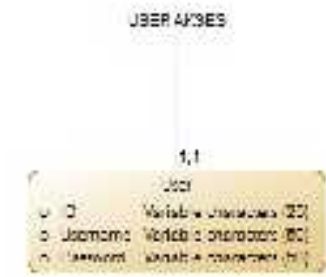

Gambar 5. Conceptual Data Model (CDM)

4.7 Implementasi Sistem

A. Implementasi Antarmuka

\section{Halaman Home}

Gambar 6 yaitu halaman Home, halaman Home ini sebagai halaman pembuka setelah login yang berisikan ucapan selamat datang untuk user yang telah login. Setelah login Pada halaman ini juga terdapat header menu yang berisikan menu Data PIC dan Data Pekerjaan. Pada halaman Home ini juga terdapat pesan untuk memilih salah satu menu diatas untuk memulai aktifitas pekerjaan.

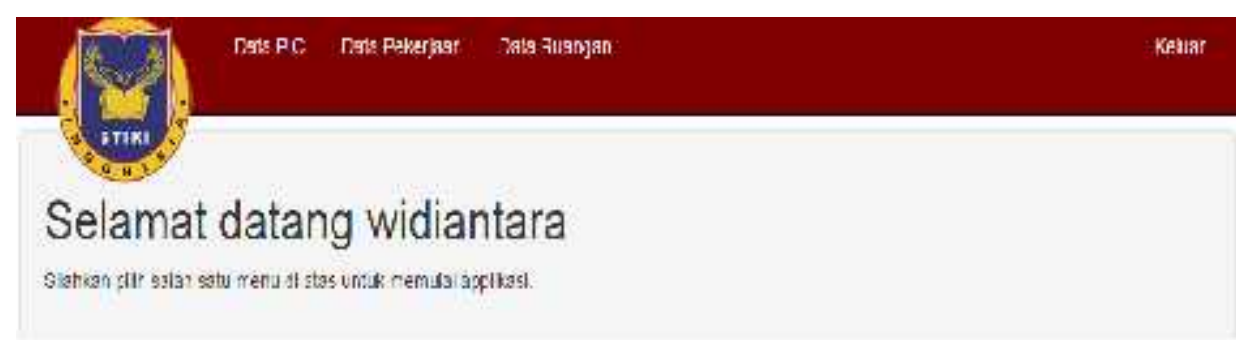

Gambar 6. Halaman Home 


\section{Halaman Data PIC}

Gambar 7 dapat dijelaskan halaman data PIC yaitu berisikan data PIC yang melakukan tindakan perbaikan pada pekerjaan yang di inputkan ke dalam data pekerjaan oleh staff PK2.

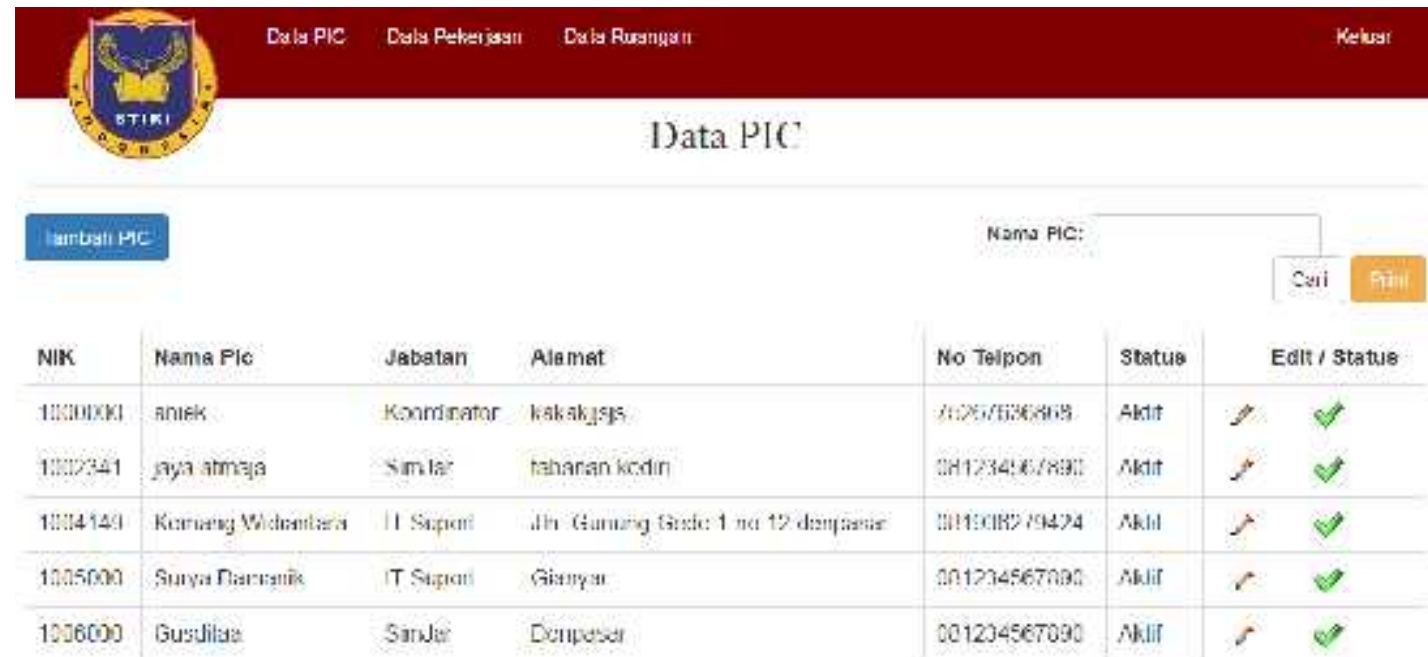

Gambar 7. Halaman Data PIC

Pada gambar 7 halaman data PIC ini berisikan 6 atribut, yaitu atribut NIK, Nama PIC, Jabatan, Alamat, Nomor telepon, dan Status. Pada halaman data PIC terdapat fungsi tambah PIC untuk menambah data PIC apabila ada PIC baru, edit PIC sebagai perbaikan data PIC, cari data PIC dan non aktif PIC yang dilakukan apabila PIC tersebut dipindahkan kedivisi lain atau berhenti kerja (resign).

\section{Halaman Data Ruangan}

Pada Gambar 8 halaman Data Ruangan digunakan untuk menambah data ruangan yang ada di kampus STIKOM Indonesia. Form ini dibuat untuk dapat menginformasikan letak peralatan elektronik yang rusak, sehingga bagian teknisi lebih cepat mengetahui letak barang elektronik yang harus diperbaiki.

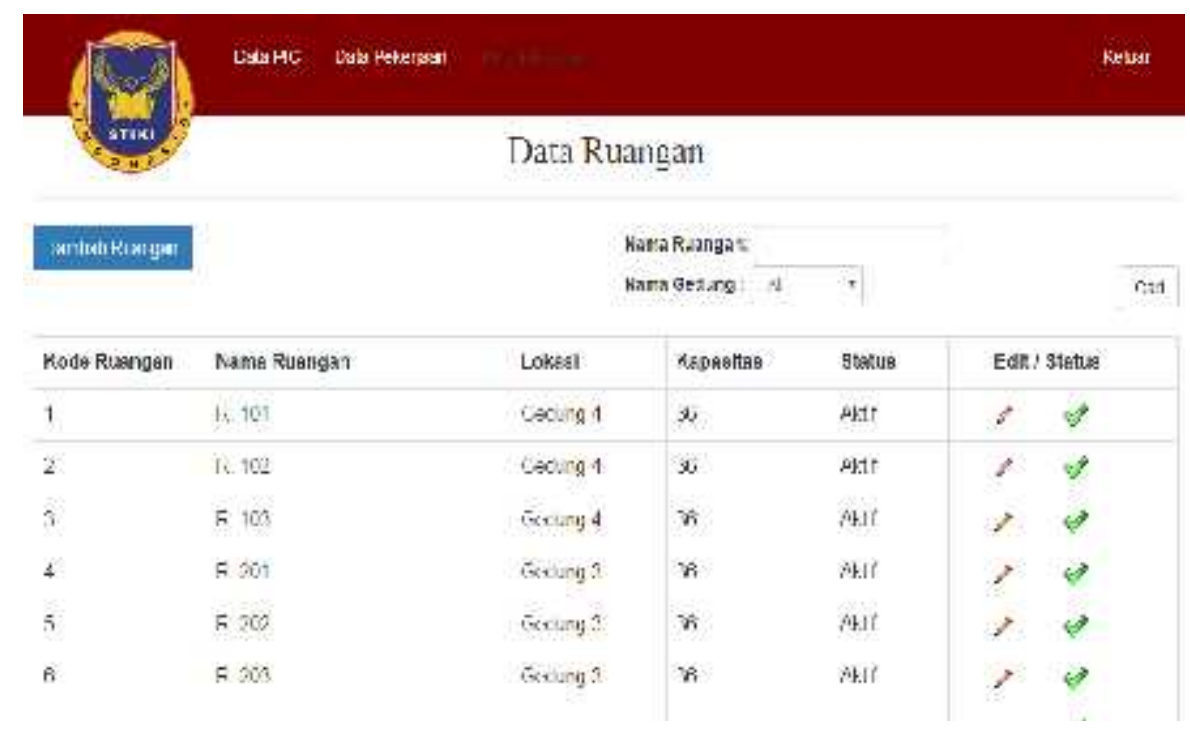

Gambar 8. Halaman Data Ruangan 


\section{Halaman Data Pekerjaan}

Pada Gambar 9 Halaman Data Pekerjaan, pada halaman ini terdapat data-data pekerjaan mulai yang baru di inputkan, sedang proses pengerjaan, pending, ready tetapi belum di validasi (pekerjaan yang sudah di perbaiki PIC) tetapi belum divalidasi oleh staff PK2 dan data pekerjaan yang sudah di validasi (sudah dinyatakan bisa di pergunakan).Halaman ini merupakan halaman terpenting karena isi dari point pada sistem ini, yaitu data pemeliharaan fasilitas baik yang sudah selesai maupun yang sedang proses.

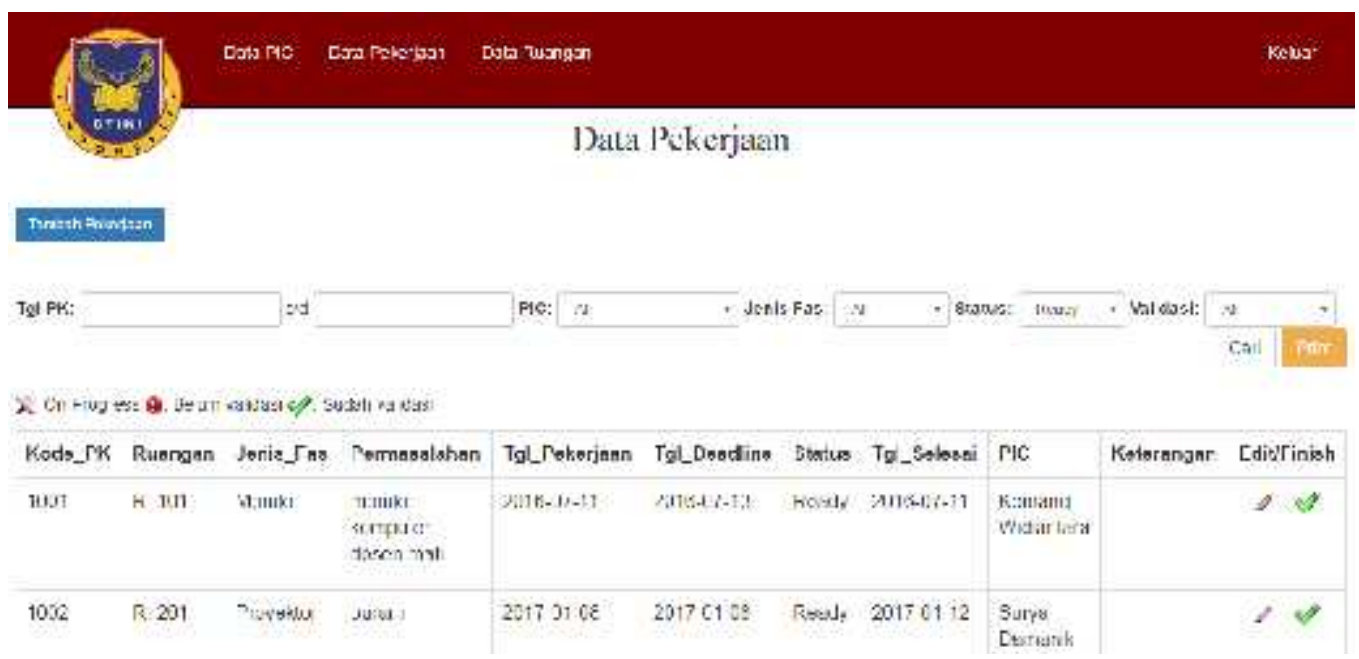

Gambar 9. Halaman Data Pekerjaan

Pada gambar 9 halaman pekerjaan ini seperti yang sudah di jelaskan diatas tentang pekerjaan yang sudah di validasi, pekerjaan yang sudah di validasi (sudah dinyaatakan dapat di pergunakan kembali) tidak dapat di validasi kembali, secara otomatis fungsi tersebut tidak akan merespon dan begitu juga untuk pekerjaan yang statusnya belum dinyatakan ready (siap / selesai) tidak dapat divalidasi. Yang mempunyai wewenang untuk data pekerjaan ini hanyalah yang memiliki user akses sebagai admin, apabila user akses sebagai teknisi fungsi validasi tidak akan dimunculkan oleh sistem.

\section{Halaman Edit Status}

Jika pekerjaan sudah diselesaikan, maka teknisi mengubah status dari pekerjaan menjadi Ready,sedangkan jika teknisi harus melakukan penggantian komponen terhadap alat yang rusak maka teknisi mengubah status menjadi Pending karena harus melakukan pengajuan pembelian peralatan dahulu. Hal tersebut ditunjukkan pada gambar 10.

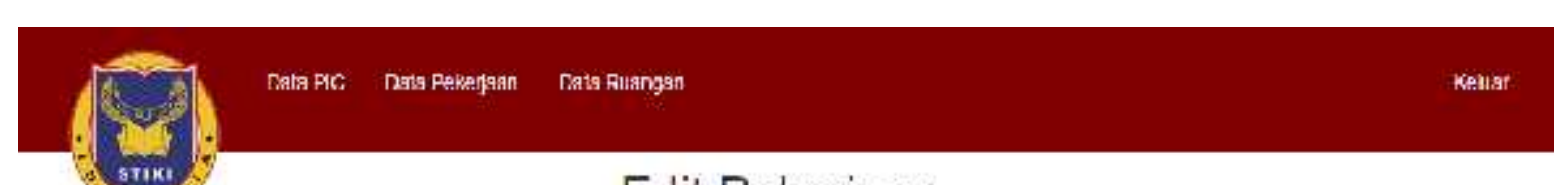

\section{Edit Pekerjaan}

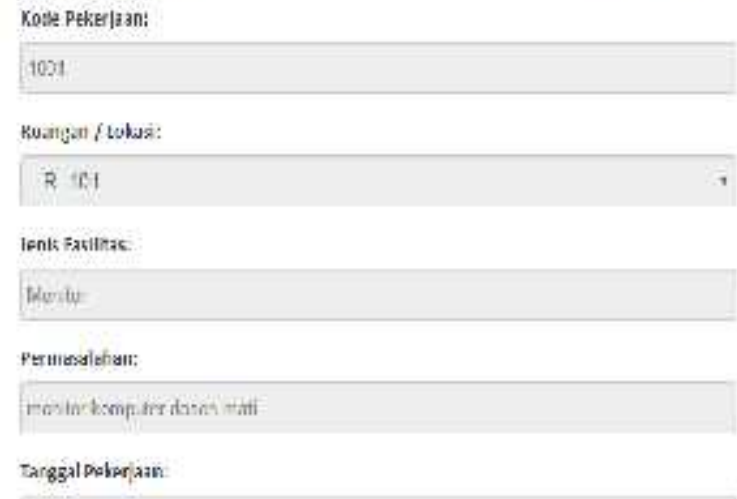
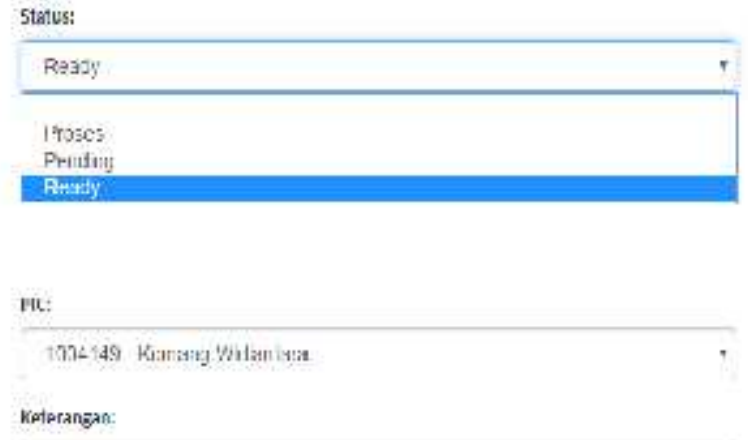

Gambar 10. Halaman Edit Status 
Teknisi dapat mengisi tanggal diselesaikannya pekerjaan yang telah diberikan dengan cara mengubah form data pekerjaan yang tampak pada gambar 11 dan mengisi tanggal diselesaikan sesuai dengan tanggal teknisi menyelesaikan pekerjaan tersebut.

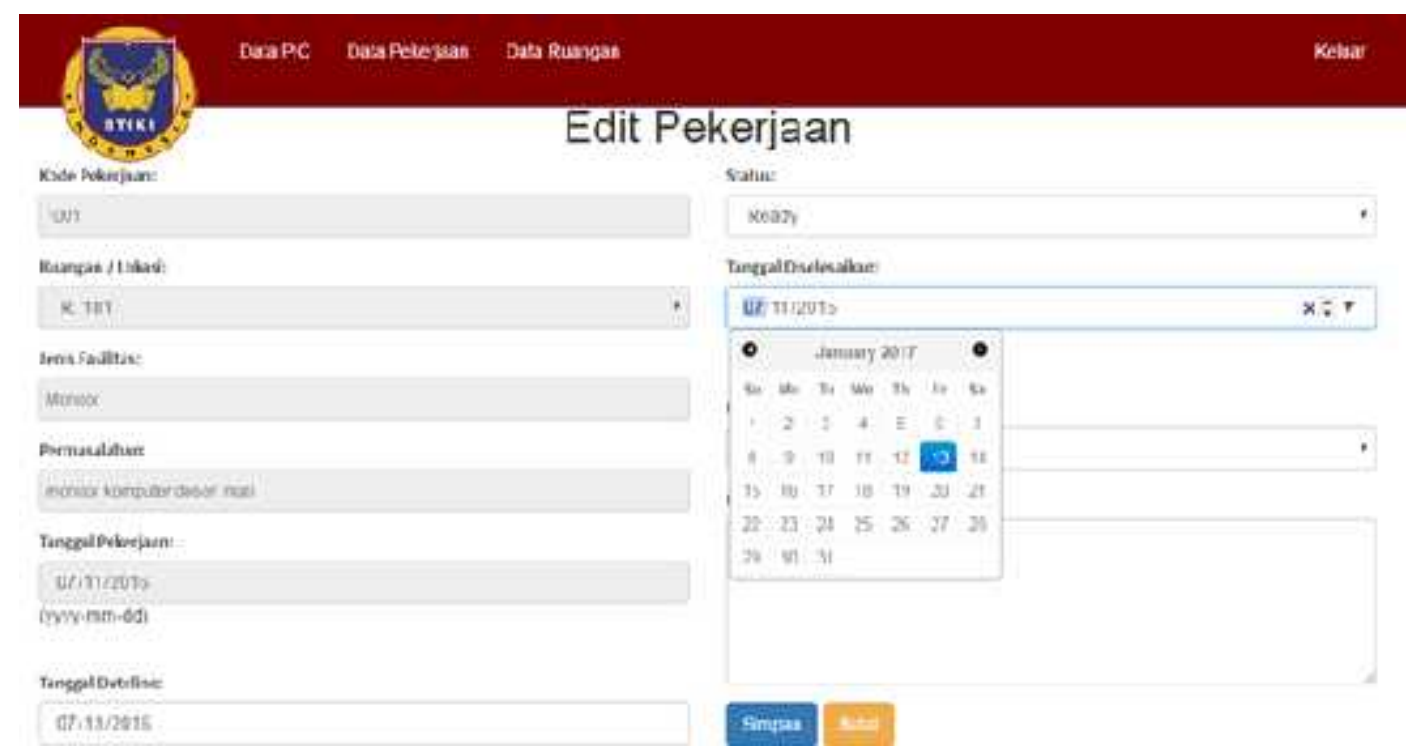

Gambar 11. Halaman Edit Tanggal Selesai Pekerjaan

\section{Halaman Validasi Pekerjaan}

Pada gambar 12 dapat dijelaskan bahwa pada Form Validasi Pekerjaan ini dilakukan oleh pihak staff PK2, dengan cara mengganti status pada kolom Edit/Finish. Sebelum melakukan validasi, staff PK2 mengecek pekerjaan yang dilakukan oleh teknisi terlebih dahulu.

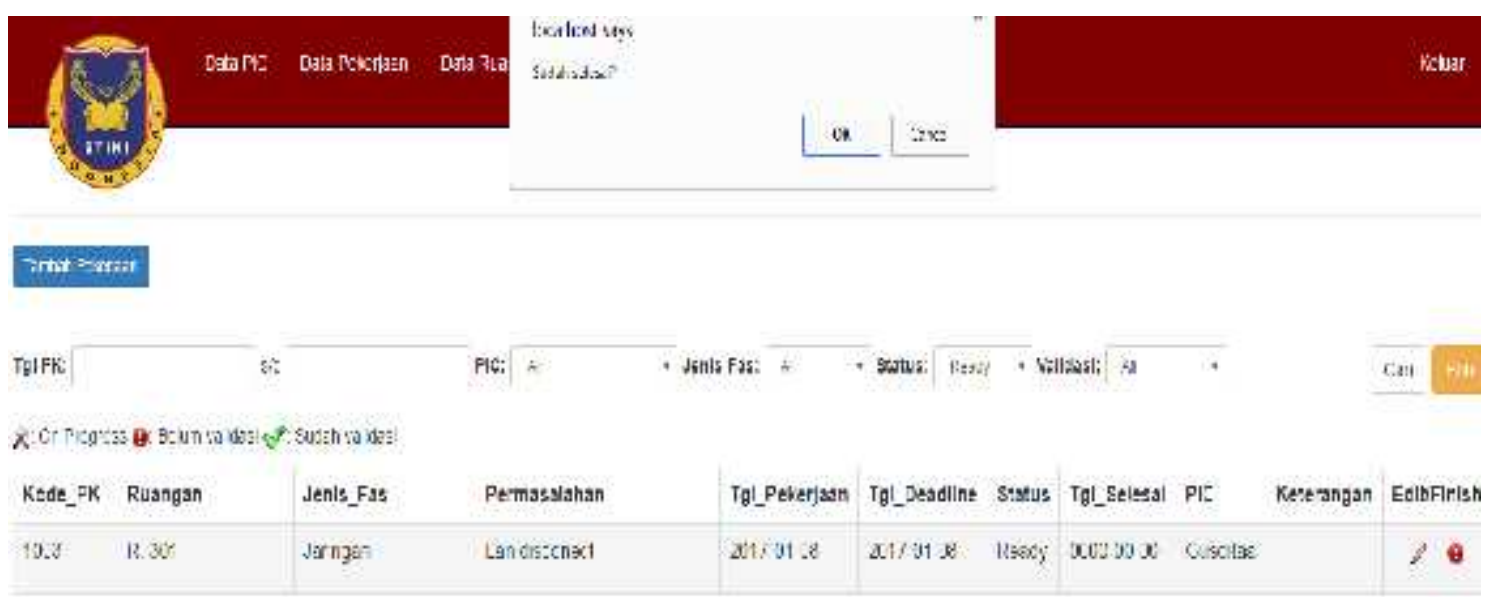

\section{B. Pengujian Sistem}

Gambar 12. HalamanValidasi Pekerjaan

Pengujian sistem menggunakan metode blackbox bertujuan untuk memastikan semua komponen dan fungsi dari sistem telah berjalan sesuai dengan harapan. Adapun hasil dari pengujian sistem menggunakan metode blackbox dapat dilihat pada Tabel 3. 
Tabel 3. Hasil Pengujian Sistem

\begin{tabular}{|c|c|c|c|c|c|}
\hline No & Komponen & Skenario Uji & Input & $\begin{array}{c}\text { Output } \\
\text { Diharapkan }\end{array}$ & $\begin{array}{c}\text { Hasil } \\
\text { Pengujian }\end{array}$ \\
\hline 1 & Validasi Login & $\begin{array}{l}\text { Masukkan username } \\
\text { dan password yang } \\
\text { benar }\end{array}$ & $\begin{array}{l}\text { Username }=\text { admin } \\
\text { Password }=\text { admin }\end{array}$ & $\begin{array}{l}\text { Masuk ke Menu } \\
\text { Utama }\end{array}$ & Halaman Home \\
\hline 2 & Validasi Login & $\begin{array}{l}\text { Masukkan username } \\
\text { dan password yang } \\
\text { salah }\end{array}$ & $\begin{array}{l}\text { Username }=\text { admin } \\
\text { Password }=1234\end{array}$ & $\begin{array}{l}\text { Gagal login dan } \\
\text { kursor kembali } \\
\text { ke username }\end{array}$ & $\begin{array}{l}\text { Gagal login dan } \\
\text { masuk ke Menu } \\
\text { Login lagi }\end{array}$ \\
\hline \multirow[t]{2}{*}{3} & \multirow[t]{2}{*}{$\begin{array}{l}\text { Pengelolaan } \\
\text { data PIC }\end{array}$} & $\begin{array}{l}\text { Admin memasukkan } \\
\text { data PIC }\end{array}$ & Data PIC & $\begin{array}{l}\text { Data dapat } \\
\text { ditambah dan } \\
\text { tersimpan ke } \\
\text { dalam tabel }\end{array}$ & $\begin{array}{l}\text { Data dapat } \\
\text { ditambah dan } \\
\text { tersimpan ke } \\
\text { dalam tabel. }\end{array}$ \\
\hline & & $\begin{array}{l}\text { Admin merubah data } \\
\text { PIC }\end{array}$ & $\begin{array}{l}\text { Perubahan Data } \\
\text { PIC }\end{array}$ & $\begin{array}{l}\text { Data PIC dapat } \\
\text { dirubah sesuai } \\
\text { inputan dari } \\
\text { user }\end{array}$ & $\begin{array}{l}\text { Data PIC dapat } \\
\text { dirubah dan } \\
\text { tersimpan dalam } \\
\text { tabel. }\end{array}$ \\
\hline \multirow[t]{2}{*}{4} & \multirow[t]{2}{*}{$\begin{array}{l}\text { Pengelolaan } \\
\text { Data Ruangan }\end{array}$} & $\begin{array}{l}\text { Admin memasukkan } \\
\text { data Ruangan }\end{array}$ & Data Ruangan & $\begin{array}{l}\text { Data dapat } \\
\text { ditambah dan } \\
\text { tersimpan ke } \\
\text { dalam tabel }\end{array}$ & $\begin{array}{l}\text { Data dapat } \\
\text { ditambah dan } \\
\text { tersimpan ke } \\
\text { dalam tabel. }\end{array}$ \\
\hline & & $\begin{array}{l}\text { Admin merubah data } \\
\text { Ruangan }\end{array}$ & $\begin{array}{l}\text { Perubahan Data } \\
\text { Ruangan }\end{array}$ & $\begin{array}{l}\text { Data Ruangan } \\
\text { dapat dirubah } \\
\text { sesuai inputan } \\
\text { dari user }\end{array}$ & $\begin{array}{l}\text { Data Ruangan } \\
\text { dapat dirubah } \\
\text { dan tersimpan } \\
\text { dalam tabel. } \\
\end{array}$ \\
\hline \multirow[t]{2}{*}{5} & \multirow[t]{2}{*}{$\begin{array}{l}\text { Pengelolaan } \\
\text { Data Pekerjaan }\end{array}$} & $\begin{array}{l}\text { Admin memasukkan } \\
\text { data Pekerjaan }\end{array}$ & Data Pekerjaan & $\begin{array}{l}\text { Data dapat } \\
\text { ditambah dan } \\
\text { tersimpan ke } \\
\text { dalam tabel }\end{array}$ & $\begin{array}{l}\text { Data dapat } \\
\text { ditambah dan } \\
\text { tersimpan ke } \\
\text { dalam tabel. }\end{array}$ \\
\hline & & $\begin{array}{l}\text { Teknisi merubah data } \\
\text { Pekerjaan }\end{array}$ & $\begin{array}{l}\text { Perubahan status } \\
\text { Pekerjaan dan } \\
\text { tanggal selesai } \\
\text { pekerjaan }\end{array}$ & $\begin{array}{l}\text { Data Pekerjaan } \\
\text { dapat dirubah } \\
\text { sesuai inputan } \\
\text { dari user }\end{array}$ & $\begin{array}{l}\text { Data Pekerjaan } \\
\text { dapat dirubah } \\
\text { dan tersimpan } \\
\text { dalam tabel. }\end{array}$ \\
\hline 6. & $\begin{array}{l}\text { Validasi } \\
\text { Pekerjaan }\end{array}$ & $\begin{array}{l}\text { Staff PK2 melakukan } \\
\text { validasi terhadap } \\
\text { pekerjaan yang sudah } \\
\text { selesai dikerjakan }\end{array}$ & $\begin{array}{l}\text { Pengimputan } \\
\text { validasi pekerjaan }\end{array}$ & $\begin{array}{l}\text { Status berubah } \\
\text { dan muncul } \\
\text { pesan sudah } \\
\text { selesai. }\end{array}$ & $\begin{array}{l}\text { Status berubah } \\
\text { dan muncul } \\
\text { pesan sudah } \\
\text { selesai. }\end{array}$ \\
\hline
\end{tabular}

\section{KESIMPULAN DAN SARAN}

\subsection{Kesimpulan}

Berdasarkan hasil dari pembahasan dan implementasi sistem yang telah di paparkan sebelumnya, maka penulis dapat menyimpulkan beberapa hal sebagai berikut:

1. Sistem Pemeliharaan Fasilitas berhasil dibangun dengan melalui proses pengumpulan data, analisa data, perancangan dan membangun sistem.

2. Sistem Pemeliharaan Fasilitas akan digunakan untuk monitoring pekerjaan dan proses pencatatan kegiatan pemeliharaan fasilitas pada STMIK STIKOM Indonesia.

3. Sistem Pemeliharaan Fasilitas dapat menampilkan halaman data pekerjaan, data PIC, dan dapat mencetak laporan pekerjaan berdasarkan PIC, laporan pekerjaan yang belum selesai.

4. Berdasarkan hasil pengujian yang telah dilakukan dapat disimpulkan keseluruhan fungsi dari sistem dapat berjalan dengan lancar.

\subsection{Saran}

Adapun beberapa saran untuk membantu pengembangan sistem selanjutnya yang serupa yaitu :

1. Untuk kedepannya, Sistem Pemeliharaan Fasilitas ini dapat ditambahkan fitur pelaporan kerusakan dari user/client dimana user/client hanya bisa mengakses form tambah kerusakan untuk pelaporan ke sistem 
2. Untuk mempermudah user/client dalam melaporkan kerusakan pada sistem, diharapkan form pelaporan menggunakan berbasis Android agar mudah di akses dari handphoneuser/client sendiri.

\section{DAFTAR PUSTAKA}

[1] Al Fatta, Hanif. 2007. Analisis dan Perancangan Sistem Informasi. Yogyakarta : ANDI.

[2] Jogiyanto HM. 2005.Analisis \&Desain : Sistem Informasi Pendekatan Terstruktur Teori dan Praktik Aplikasi Bisnis. Yogyakarta : ANDI

[3] Kadir, Abdul. 2003. Pengenalan Sistem Informasi. Yogyakarta : ANDI

[4] Kusrini.2007.Strategi Perancangan dan Pengelolaan Basis Data.Yogyakarta : ANDI

[5] Millman, J. 1979. Micro Electronics. Tokyo : McGraw Hill International Book Company.

[6] Pressman, Roger. S. 2002. Rekayasa Perangkat Lunak Pendekatan Praktisi (Buku 1). ANDI : Yogyakarta

[7] Simarmata, Janner. 2007. Perancangan Basis Data.Yogyakarta : ANDI

[8] Sudirman, Ivan dan Wahono, Romi Satria. 2003. Kuliah Pengantar IlmuKomputer.Com: Sejarah Komputer. IlmuKomputer.Com. 